NBER WORKING PAPER SERIES

\title{
SPATIAL MISMATCH, IMMIGRANT NETWORKS, AND HISPANIC EMPLOYMENT IN THE UNITED STATES
}

\author{
Judith K. Hellerstein \\ Melissa McInerney \\ David Neumark \\ Working Paper 15398 \\ http://www.nber.org/papers/w15398
}

\author{
NATIONAL BUREAU OF ECONOMIC RESEARCH \\ 1050 Massachusetts Avenue \\ Cambridge, MA 02138 \\ October 2009
}

This research was supported by NICHD grant R01HD042806. The research in this paper was conducted while McInerney was employed by the U.S. Census Bureau. We are grateful to two anonymous referees for helpful comments. We thank Kyle Handley for outstanding research assistance. This paper has undergone a Census Bureau review more limited in scope than that given to official Census Bureau publications. It has been screened to ensure that no confidential information is revealed. Research results and conclusions expressed are those of the authors and do not necessarily indicate concurrence by the Census. The views expressed herein are those of the author(s) and do not necessarily reflect the views of the National Bureau of Economic Research.

NBER working papers are circulated for discussion and comment purposes. They have not been peerreviewed or been subject to the review by the NBER Board of Directors that accompanies official NBER publications.

(C) 2009 by Judith K. Hellerstein, Melissa McInerney, and David Neumark. All rights reserved. Short sections of text, not to exceed two paragraphs, may be quoted without explicit permission provided that full credit, including $(\mathcal{C}$ notice, is given to the source. 
Spatial Mismatch, Immigrant Networks, and Hispanic Employment in the United States

Judith K. Hellerstein, Melissa McInerney, and David Neumark

NBER Working Paper No. 15398

October 2009

JEL No. J1,J61

\begin{abstract}
$\underline{\text { ABSTRACT }}$
We study the relationship between Hispanic employment and location-specific measures of the distribution of jobs. We find that it is only the local density of jobs held by Hispanics that matters for Hispanic employment, that measures of local job density defined for Hispanic poor English speakers or immigrants are more important, and that the density of jobs held by Hispanic poor English speakers are most important for the employment of these less-skilled Hispanics than for other Hispanics. This evidence is consistent with labor market networks being an important influence on the employment of less-skilled Hispanics, as is evidence from other sources. We also find that in MSAs where the growth rates of the Hispanic immigrant population have been highest, which are also MSAs with historically low Hispanic populations, localized job density for low-skilled jobs is even more important for Hispanic employment than in the full sample. We interpret this evidence as consistent with the importance of labor market networks, as strong labor market networks are likely to have been especially important in inducing Hispanics to migrate, and because of these networks employment in these "new immigrant" cities is especially strongly tied to the local availability of jobs.
\end{abstract}

Judith K. Hellerstein

Department of Economics

Tydings Hall

University of Maryland

College Park, MD 20742

and NBER

hellerst@econ.umd.edu

Melissa McInerney

College of William and Mary

and U.S. Census Bureau

Economics Department

P.O. Box 8795

Williamsburg, VA 23187

mcinerney@econ.umd.edu
David Neumark

Department of Economics

UCI

3151 Social Science Plaza

Irvine, CA 92697

and NBER

dneumark@uci.edu 


\section{Introduction}

Employment rates of Hispanic males in the United States are considerably lower than employment rates of whites. In the data used in this paper, the Hispanic male employment rate is 61 percent, compared with 83 percent for white men. ${ }^{1}$ The question of the employment disadvantage of Hispanic men likely has many parallels to the question of the employment disadvantage of black men, where factors including spatial mismatch, skills, discrimination, and labor market networks have all received attention as contributing factors. However, the Hispanic disadvantage has been much less studied, and the goal of this paper is to bridge that gap. To that end, we present evidence that tries to better understand the Hispanic employment disadvantage in the United States. We touch on all of these factors, but focus primarily on spatial mismatch and immigrant networks.

In addition to providing evidence for a less-studied minority group in the United States, we believe that evidence on U.S. Hispanics is more likely to be generalizable to immigrant populations in Western Europe than is evidence on U.S. blacks. There appear to be more parallels between the situations of the Hispanic immigrant population in the United States and major immigrant populations in Western Europe than there are between the situations of blacks in the United States and immigrants in Europe, including: language differences in some cases, such as Turks in Germany (Hillman, 2002) and Asians in Sweden (Zenou et al., 2006); residence in ethnic enclaves (Schönwälder, 2007; Drever and Clark, 2006); continuing economic and political ties with the origin countries of the immigrants; and of course the absence of a history of slavery. ${ }^{2}$ Naturally, though, any explicit conclusions about particular European countries and populations of interest would have to come from similar analyses of data covering those areas.

The spatial mismatch hypothesis is used primarily to try to help explain the employment gap between blacks and whites. The hypothesis argues that the lower employment rate of blacks is in part attributable to there being "fewer jobs per worker in or near black areas than white areas" (Ihlanfeldt and Sjoquist, 1998, p. 851), because of exogenous residential segregation by race attributable at least in part to

\footnotetext{
${ }^{1}$ The data are described in detail below; they cover urban residents in the 2000 Decennial Census of Population.

${ }^{2}$ For more general discussion, see, for example, Kastoryano and Harshav (2002) and Gobillon and Selod (2007).
} 
discrimination in housing markets. Our recent research suggested, however, that spatial mismatch is not the mechanism by which residential segregation leads to poor economic outcomes for blacks (Hellerstein et al., 2008a). In particular, we find that poor employment outcomes for low-skilled blacks are not a function of a lack of jobs per se where blacks live, but rather that local blacks get these jobs only when employers are hiring other black workers - a phenomenon we termed "racial mismatch.” Note that the term "racial mismatch” is not intended to suggest that space is not important. When there is racial mismatch, the spatial distribution of jobs is still important, but it is the spatial distribution of jobs held by blacks that is central to black employment. The key difference is that we cannot have racial mismatch unless race plays an independent role in employment. While "racial mismatch" is a convenient short-hand for this alternative hypothesis, and we use it from here, the hypothesis is one about the interaction of space and race, which might best be thought of as "spatial-racial mismatch."3

The evidence of racial mismatch is consistent with the existence of race-based networks. Moreover, in subsequent research (Hellerstein et al., 2008b) we have found additional evidence of network effects. Workers employed by the same establishment are much more likely to live in the same neighborhood than would be expected to occur at random among people working in the same area, even conditional on skill. This is true for (non-Hispanic) whites and for blacks; but it is especially true for Hispanics, and even more so for poor-English-speaking Hispanics. Moreover, we find that networks appear to be stratified by race, potentially explaining why the employment of blacks is boosted by high black job density where they live. Finally, in other work that two of us have done, we find evidence of substantial workplace segregation by race and ethnicity, evidence that is also consistent with race- and ethnicity-based labor market networks (Hellerstein and Neumark, 2008).

In this paper we ask similar questions about the determinants of Hispanic employment. To some extent we follow the analysis in Hellerstein et al. (2008a). Paralleling that work as well as that of others on spatial mismatch and networks, we are particularly interested in low-skilled Hispanics. Clearly Hispanics

\footnotetext{
${ }^{3}$ Indeed the analysis also conditions on skill level, so there are really three dimensions of interest - space, race (or ethnicity in this paper), and skill.
} 
who are poor English speakers are low-skilled relative to the U.S. labor market. Immigrants more generally may also be low-skilled, owing to both lower education and lack of assimilation, as well as language. Nonetheless, poor English appears to be the most obvious marker of low skills. Of course the overlap between poor English speakers and immigrants is substantial. In particular, nearly all poor English speaking Hispanics are immigrants (93.1 percent), and virtually no non-immigrants are poor English speakers (4.6 percent). Being an immigrant is also a marker for poor English ability, although the relationship is not as strong; 45.2 percent of the immigrant sample consists of poor English speakers. We therefore focus much of our discussion on poor English speakers.

For Hispanics overall, and in particular for poor English speakers and for immigrants, we find evidence paralleling the “racial mismatch” results for blacks; Hispanic employment is higher when Hispanic job density is higher. This is particularly true for the subgroup of poor-English-speaking Hispanics when job density is defined for the same subgroup. These results, coupled with what we have learned from our previous research, and especially with the finding that similar employment patterns exist for low-skilled whites, lead us to conclude that networks play a key role in employment outcomes. In order to further assess our network explanation, we present new evidence from metropolitan areas with high growth rates of the Hispanic labor force, where networks should play an especially important role; we find an even more important role for Hispanic job density in the employment of low-skilled Hispanics in these areas than in the national sample.

The implications of our findings are significant. If spatial mismatch is the principal reason why minority groups have lower employment rates, then their employment rates could be increased by improving minority access to areas with more jobs (at the appropriate skill level), without regard to the racial or ethnic composition of employment in those jobs. This could be done by improved transportation such as "Wheels to Work" and other programs to increase access of low-income workers to cars (Goldberg, 2001) - or by explicit programs to move minorities away from areas with low concentrations of employment - such as “Moving to Opportunity” (Katz et al., 2001). Interestingly, many evaluations of these programs suggest that they are relatively ineffective at increasing black employment. Although these 
results may be surprising, if networks are fundamental, then policies that aim to increase employment of minorities in neighborhoods further away from where they originally live are likely to prove ineffective and perhaps even counterproductive, by taking these individuals away from networks that provide them with information about jobs.

\section{Relationship to Existing Research on Spatial Mismatch and Labor Market Networks}

The classic early study of spatial mismatch was by Kain (1968), who drew three conclusions from data on Chicago and Detroit: (i) blacks were less likely to be employed in areas with lower shares of black residents; (ii) black employment would be considerably higher if there were less racial segregation in housing; and (iii) jobs had moved from central city areas to suburban areas between 1950 and 1960, combining with segregation of blacks in central city areas to depress further black employment prospects. Subsequent research largely follows Kain in studying spatial mismatch in the context of black employment. This research takes a number of different approaches. Some studies look at employment (or earnings) differences associated with urban (central city) residence versus suburban residence (e.g., Harrison, 1972; Vrooman and Greenfield, 1980; Price and Mills, 1985). Others try to incorporate more direct information on job access related to either travel time or the extent of nearby jobs within a metropolitan area (e.g., Ellwood, 1986; Ihlanfeldt and Sjoquist, 1990). This latter approach is more similar to what we do in our tests of spatial mismatch, although we incorporate a good deal more information on the availability of jobs. A third line of research uses across-city variation in the spatial distribution of jobs to test for spatial mismatch. This work is closer to ours in that it uses data from a large set of metropolitan areas (rather than a few). But it differs because of the level of aggregation; we simultaneously use data from metropolitan areas across the country, but do the analysis at a disaggregated level within cities. Each of these approaches, perhaps not surprisingly, is subject to some criticism, outlined in Hellerstein et al. 
(2008a). And of course all of them potentially suffer from the endogeneity of residential location. ${ }^{4}$

In contrast to nearly all of the existing work on spatial mismatch, in this paper we focus on Hispanics. Indeed, there are only a few previous studies of spatial mismatch for Hispanics. Both Kain’s (1992) review of the literature on spatial mismatch and Holzer's (1991) review cite only one study of Hispanics (Farley, 1987). A more recent review of spatial mismatch by Ihlanfeldt and Sjoquist (1998), however, cites a few newer studies that present evidence that spatial mismatch also matters for employment of Hispanics (McLafferty and Preston, 1992 and 1996; Taylor and Ong, 1995; Thompson, 1997; and Blumenberg and Ong, 1998). And a recent example that considers both black and Hispanic workers is Fernandez (2008).

Our approach also differs from the existing work on spatial mismatch. Unlike the city-level analyses, we are interested in how the distribution of jobs across narrowly-defined local labor markets within cities affects employment, and hence we conduct a more disaggregated analysis, using measures of job access at a considerably more-detailed level, constructed from confidential Census information on place of work and place of residence. Because of the large sample and other features of our data, we are also able to construct job access measures by skill, which may provide a better characterization of spatial mismatch facing particular groups of individuals. Moreover, in the case of Hispanics (and in contrast to the existing, small literature), we focus especially on poor English speakers, a subgroup that consists almost exclusively of immigrants.

The more substantive departure from the previous literature, however, is that we do not only estimate the effects of job density on Hispanic employment. We also construct separate measures of job density by Hispanic/non-Hispanic ethnicity (and both language ability and immigrant status), and estimate

\footnotetext{
${ }^{4}$ Some researchers have been willing to posit the existence of valid instruments for city-level analyses. For example, Weinberg (2004) uses as instruments the industrial composition of a city's employment, information on the housing stock, and historical black residential concentration. Cutler and Glaeser (1997) instrument for city-level racial segregation in housing with variables capturing the local structure of government and topographical features of the city. In these papers, accounting for endogeneity with instrumental variables estimation has little effect on the results. Zenou et al. (2006) have a different approach to the endogeneity problem, because they have data in which immigrants (refugees) were assigned to a residential location by the government, based on no more information than
} 
whether Hispanic employment is more sensitive to the spatial distribution of jobs held by Hispanics (or Hispanics with the same language proficiency skills or who are immigrants), than to job density measured without regard to ethnicity. ${ }^{5}$ This particular test regarding the effects of job density on Hispanic employment is likely less prone to biases from endogenous residential location that may arise in research on spatial mismatch. In particular, the biases stemming from unobservable characteristics of workers are likely to bias the coefficients on ethnicity-specific job density measures similarly. Thus, there is arguably less concern that this source of bias generates a difference in the estimated effects of job density defined for Hispanics and non-Hispanics, which is the difference of central interest in this paper. Nonetheless, we do not have an explicit solution to the classic problem of endogenous residential location that arises in this and many areas of urban economics. We cannot, therefore, rule out a particular pattern of residential sorting that is associated with the different job density measures so as to generate our results; all we can argue is that it is less plausible that sorting generates the type of evidence we find, relative to its role in generating the more simple type of evidence associated with spatial mismatch.

Evidence that it is the density of jobs held by Hispanics, in particular, that affects Hispanic employment, is not consistent with the pure spatial mismatch hypothesis, which emphasizes only the spatial location of jobs. It is, however, consistent with network models of the labor market. Montgomery (1991) specifies a labor market in which firms with vacancies cannot observe the underlying ability of a potential worker, but firms can infer something about a potential worker's ability if (and only if) the firm currently employs individuals from that worker's social network, where social networks are at least partially stratified by ability. Hence, networks act at the establishment level to reduce employer search costs. In equilibrium, individuals are more likely to receive and accept wage offers from the firms that employ others in their social network, creating stratification across firms on the basis of social networks. In

\footnotetext{
is available to the researchers. Ross (1998) also analyzes spatial mismatch at the metropolitan statistical area (MSA) level, although he focuses on changes in jobs and residential location.

${ }^{5}$ The only study we have found that looks at job density by demographic group is by Ellis et al. (2007), who examine how the residential distribution of immigrant groups and the spatial distribution of employment in the industries in which immigrant groups work interact to determine, within one metropolitan area (Los Angeles), variation in the industries in which different immigrant groups are concentrated.
} 
Montgomery's framework, if social networks are at least partially ethnic-based, perhaps due to differences in languages spoken across ethnic groups, then we would expect Hispanic employment to be higher in areas that are more dense with Hispanic employment. ${ }^{6}$

We take the empirical analysis one step further and implement a test for the network interpretation of the link between Hispanic job density and employment of Hispanic residents. Immigrants to the United States historically have tended to migrate to areas where previous immigrants from their home countries have settled (see, e.g., LaFortune, 2008). For Hispanic immigrants, traditional receiving areas have been metropolitan Los Angeles, South Texas, and South Florida. The persistence of the spatial distribution of immigration patterns clearly suggests the importance of immigrant enclaves in helping to secure economic stability. Strikingly, however, between 1990 and 2000, a period in which the Hispanic population of the United States doubled, Hispanics established sizable communities in cities that traditionally had small Hispanic populations, with the growth of Hispanic communities in these cities driven primarily by changes in the destinations of new migrants to the United States. ${ }^{7}$

To provide an example, our tabulations from 1990 and 2000 Census data indicate that the Greensboro-Winston Salem-Highpoint MSA had fewer than 1,000 non-U.S.-born Hispanic adult males in 1990, but a decade later had over 20,000. Given the high transaction costs of migration, net migration of over 2,000 percent in a decade suggests that these new migrants had information that the returns to moving to the Greensboro area were high - or more specific information that would make the returns high for them - exactly the kind of information that labor market networks might supply. Moreover, network contacts in these new communities may have been especially important in securing employment for new migrants, given that the local economies did not have long histories of Hispanic employment and given that employers in these areas did not have much experience with Hispanic workers, especially those with poor English language ability. As a consequence, if the relationship between density of jobs for Hispanics and

\footnotetext{
${ }^{6}$ Strictly speaking, we might expect Hispanic employment to be higher when more Hispanic residents are employed, if networks operate largely along residential lines. But network-related contacts may also flow among those employed in the same area even if they are not all co-resident.

${ }^{7}$ Card and Lewis (2007) study the diffusion of Mexican immigrants over the decade.
} 
employment of poor-English-speaking Hispanic residents is particularly strong in the cities that experienced rapid recent growth of Hispanic immigrants, it is likely that this relationship is driven by network effects.

\section{$\underline{\text { III. Data }}$}

We use the 2000 Sample Edited Detail File (SEDF), which contains all individual responses to the 2000 Decennial Census one-in-six Long Form, and detailed information on residential location and place of work. The SEDF includes the individual-level controls provided in the Census, allowing us to capture differences in skills and other characteristics across individuals that may affect employment. But the key feature that these data provide from the perspective of studying spatial mismatch is the ability to construct measures of job density for highly disaggregated geographic areas within MSAs using a very large sample. The job density measure on which we rely in most of our analyses is the number of jobs in the area relative to the population residing there, in the aggregate and for subsets of the population. In all cases, the density measures assigned to each Census respondent are calculated excluding that individual, to avoid a mechanical relationship between job density and an individual's employment. Job density parallels the concept of "job accessibility" that figures prominently in research on spatial mismatch, although in much of the earlier research it was common to measure this accessibility indirectly via commuting time. ${ }^{8}$

The definition of these job density measures requires the specification of the relevant local labor market. The idea is to consider a geographic unit in which the availability of jobs has an important influence on residents of that geographic unit. A city (or MSA/PMSA) is likely much too large. On the other hand, single zip codes are likely too small. ${ }^{9}$ We instead focus our attention on “zip code areas,” defined by the zip code and all geographically contiguous zip codes. About a third of the employed individuals in our sample work in the "zip code area” in which they reside, compared with 15 percent working in the zip code in which they live, and 90 percent in the same MSA/PMSA. These figures suggest

\footnotetext{
${ }^{8}$ In contrast, Raphael (1998) and Fernandez (2008) are examples of more recent work that looks directly at accessibility of jobs.

${ }^{9}$ Zip code areas contain numerous Census blocks, but do not cover large areas of land. See Hellerstein et al. (2008a).
} 
that zip code areas capture a relatively compact geographic area in which many residents look for and find employment. $^{10}$

Table 1 describes the construction of the sample of Hispanic males used in this paper. As shown in the top two rows, the full SEDF includes 42.6 million (non-institutionalized) observations, with over 2.3 million observations on Hispanic males. The following five rows indicate how many of these observations (on Hispanic men) would be excluded based on a number of criteria for exclusion from the sample; each criterion is considered separately, rather than specifying an arbitrary order for imposing them and the number of observations dropped at each step. Four of the exclusion criteria are very significant: living outside a metropolitan area, being outside the age range, current school enrollment (which is closely related to age), and having a work-limiting disability. Imposing all of these criteria jointly yields 865,354 observations on Hispanic men.

Subsequent rows address particular problems that arise because we need to identify both where people live and where they work. First, a small number of observations report a zip code for either place of work or place of residence that is on the water, rather than on land. (For example, an oil rig would be a work location on the water.) These zip codes have very few residents or workers (and often only one or the other) and therefore have meaningless measures of job density, so we exclude them. There are a few observations with unmatched information on place of work, which arises when one's place of work is in a zip code that does not get included in the file we use to create contiguous zip codes. Far more prevalent are cases where the place of work has been allocated rather than reported by the respondent, which occur about one-fourth of the time. Because we want to be sure to accurately measure place of work, and because our examination of the allocated cases suggested that allocated places of work are essentially chosen to be random places within metropolitan areas, we drop these cases. However, because the incidence of missing

\footnotetext{
${ }^{10}$ Technically, the 2000 Decennial Census reports Zip Code Tabulation Areas (ZCTA's) rather than the more traditional postal zip codes, although there is a one-to-one mapping of the two definitions in most cases; we therefore simply refer to ZCTA's as zip codes. Some ZCTA's are actually disjoint sets of Census blocks. In those (relatively rare) cases, we treat the disjoint sets as two separate zip codes. For each zip code, we use ArcView to map the zip codes contiguous to each zip code to form our "zip code areas." A single zip code therefore is likely to be part of multiple zip code areas in our data.
} 
place of work information is non-random with respect to observable characteristics, we reweight to obtain a representative sample. ${ }^{11}$ These weights are used in all descriptive statistics and regressions.

The final set of sample restrictions ensures that the job density measures are defined for the remaining observations. In particular, because the denominators of the density measures are the numbers of individuals with given characteristics living in the zip code area, these denominators occasionally can be zero. We drop from all of the regressions we estimate all data in zip code areas with undefined density measures, so that the various estimates can be compared across a consistent sample, ${ }^{12}$ as well as observations with missing zip codes. The final number of SEDF observations on Hispanic men is 625,523.

\section{Empirical Approach}

\section{Test of Spatial Mismatch}

The analysis of spatial mismatch uses the sample of Hispanic men in the SEDF living in MSAs.

The first specification we estimate simply includes an aggregate job density measure $(J D)$ as well as a standard vector of controls, as in

$$
E=\alpha+X \beta+\delta J D+\varepsilon \cdot \cdot^{13}
$$

The spatial mismatch model implies that job density should be an important determinant of employment $(E)$, predicting that $\delta$ is positive. ${ }^{14}$ The variables in $X$ include: age (linear and quadratic terms), marital status (a dummy variable for currently married), education (dummy variables for high school degree, some college, Associate’s degree, Bachelor’s degree, and advanced degree), English language proficiency (dummy variables for speaking English “not at all,” “not well,” “well,” or “very well”), a

\footnotetext{
${ }^{11}$ For the sample of employed workers, we estimated a linear probability model for unmatched or allocated place of work information as a function of all of the demographic controls used in the regressions described below. We then reweighted the employed observations based on the estimates from this model, weighting by the reciprocal of the predicted probability of having valid place of work data.

${ }^{12}$ The alternative would be to drop a different set of zip code areas depending on the density measures used in each regression. The differences in resulting sample sizes are minor.

${ }^{13}$ In most cases, because the data are clustered on zip code areas and the job density variables are defined at this level, we report standard errors that are robust to non-independence of observations within zip code areas, as well as heteroscedasticity. Estimated standard errors that are clustered at the MSA level are only slightly larger, and change none of the conclusions.
} 
dummy variable for immigrant status, MSA fixed effects, and residence in a central city, non-central city, or suburb. The controls for MSA and central city, etc., are intended to capture other sources of variation in employment rates, such as wealth, industry mix, sorting of individuals, etc. Given the sample size, equation (1) is estimated as a linear probability model.

Because the spatial mismatch model also predicts that the location of jobs is more relevant for lessskilled individuals, we augment the model to allow the effects of job density to vary with skill. In the empirical analysis, we emphasize the variable we consider the most important proxy for the skill level of Hispanics - poor English-language ability. ${ }^{15}$ However, we also present parallel results using immigrant status as a proxy for skill. In this section, everything is explained in terms of the poor English proxy; the discussion carries over completely to using the immigrant proxy. The specification therefore becomes (2) $\quad E=\alpha+X \beta+\delta_{P E} J D \cdot P E+\delta_{G E} J D \cdot(1-P E)+\varepsilon$,

where $P E$ is a dummy variable for poor English skills.

While equation (2) allows for different effects of overall job density depending on individuals’ English language skills, it uses an aggregate job density measure that captures the jobs held by all workers per local resident. But if Hispanic workers are more likely to have employment prospects in labor markets characterized by low-skill jobs, using an aggregate measure of job density might understate its role in Hispanic labor markets. We therefore construct a job density measure only for those who speak English poorly. This job density restriction applies to both the numerator and the denominator, so the poor English density measure is jobs held by poor English speakers divided by residents who are poor English speakers. Thus, equation (1) becomes

$$
E=\alpha+X \beta+\delta J D_{P E}+\varepsilon,
$$

where the subscript on $J D$ in this equation indicates that job density is defined just for those who speak

\footnotetext{
${ }^{14}$ Because the numerator of the job density measures includes both residents and non-residents, our regressions are not characterized by the classic reflection problem (Manski, 1993) that would arise if we were regressing individual employment on the mean local employment rate of residents.

${ }^{15}$ We consider poor English speakers to be those whose self-reported response to the Census question on English language proficiency is either speaking English "not at all” or "not well."
} 
English poorly $(P E)$.

The specification in equation (3) may be incomplete, however, because the spatial mismatch hypothesis might lead us to expect that the density of jobs held by poor English speakers more strongly affects the employment of poor English speakers than other Hispanics, both because for these low-skilled individuals commuting is a higher fraction of the net wage, and because this skill-specific job density measure more accurately captures jobs likely to be available to poor English speakers. Equation (4) therefore captures the differential importance of the job density of poor English speakers on Hispanics of varying English proficiency:

$$
E=\alpha+X \beta+\delta_{P E} J D_{P E} \cdot P E+\delta_{G E} J D_{P E} \cdot(1-P E)+\varepsilon .
$$

The estimates of equations (1) through (4) provide increasingly-detailed tests of whether the data are consistent with the spatial mismatch hypothesis. The overall results, and how they change with the specification, provide more compelling tests of the potential existence of spatial mismatch than has much of the previous literature. Of course all of this evidence for Hispanics is somewhat novel, as nearly all of the existing research on spatial mismatch in the United States focuses on blacks, rather than Hispanics, and none looks at the dimensions of spatial mismatch that we examine.

\section{Incorporating Ethnic-Specific Job Densities}

The specifications to this point do not distinguish job density by whether the jobs are held by Hispanics or by others. However, paralleling the evidence of "racial mismatch" that we found for blacks (Hellerstein et al., 2008a), we are interested in whether Hispanic employment is more sensitive to job density for Hispanics - in contrast to the simple spatial mismatch hypothesis. To study this question, we first go back to the simplest specification (equation (1)), but we modify it to distinguish job density by ethnicity, as in

$$
E=\alpha+X \beta+\delta^{N H} J D^{N H}+\delta^{H} J D^{H}+\varepsilon .
$$

$J D^{N H}$ is non-Hispanic jobs per Hispanic resident, and $J D^{H}$ is Hispanic jobs per Hispanic resident. We actually use three alternative versions of these density measures: jobs held by non-Hispanics and jobs held by Hispanics, per Hispanic resident; jobs held by non-Hispanic men and jobs held by Hispanic men, 
per Hispanic male resident; and jobs held by white men and jobs held by Hispanic men, per Hispanic male resident. But as a short-hand the equation simply refers to Hispanic and non-Hispanic job density. ${ }^{16}$ Because we define both densities relative to Hispanic residents, estimates of the two coefficients $\delta^{N H}$ and $\delta^{H}$ allow a comparison of the effect on Hispanic employment probabilities of an additional Hispanic job per Hispanic resident to the effect of an additional non-Hispanic job per Hispanic resident. If Hispanic job density is a more important determinant of Hispanic employment, then we should find that $\delta^{H}>\delta^{N H}$ (with the first expected to be positive). In contrast, pure spatial mismatch would predict no difference between $\delta^{H}$ and $\delta^{N H}$.

We also estimate versions of equations (2)-(4) allowing for separate effects of job density by Hispanic ethnicity. To take the simplest example, equation (2) becomes

$$
E=\alpha+X \beta+\delta_{P E}{ }^{N H} J D^{N H} \cdot P E+\delta_{P E}{ }^{H} J D^{H} \cdot P E+\delta_{G E}{ }^{N H} J D^{N H} \cdot(1-P E)+\delta_{G E}^{H} J D^{H} \cdot(1-P E)+\varepsilon .
$$

The equivalent of the racial mismatch result we have found for blacks would be that Hispanic job density is a much more important determinant of employment for low-skilled Hispanics than is nonHispanic job density. Of course the skill level of the jobs available in the local labor market may also be important. For that reason, we define job density based on those with lower skills, paralleling equation (3). Finally, paralleling equation (4) we simultaneously define density based on those with lower skill levels, and allow different effects based on the worker's own skill level, so that the equation becomes:

$$
E=\alpha+X \beta+\delta_{P E}{ }^{N H} J D_{P E}{ }^{N H} \cdot P E+\delta_{P E}{ }^{H} J D_{P E}^{H} \cdot P E+\delta_{G E}{ }^{N H} J D_{P E}{ }^{N H} \cdot(1-P E)+\delta_{G E}^{H} J D_{P E}{ }^{H} \cdot(1-P E)+\varepsilon,
$$

where $J D_{P E}{ }^{H}$, for example, is jobs held by Hispanics who speak English poorly per poor-English-speaking Hispanic resident. Again, comparisons of the estimated $\delta$ 's tell us whether the relationship between job density and employment based on language skills is ethnicity-specific.

\section{$\underline{\text { V. Results }}$}

\section{Descriptive Statistics}

We begin with some descriptive statistics for Hispanic, non-Hispanic, and white men (a subset of

\footnotetext{
${ }^{16}$ The tables always clarify which group we are studying, but in the text we often simply refer to Hispanics and nonHispanics, or Hispanics and whites.
} 
non-Hispanic men), in Panel A of Table 2. The table shows that Hispanics are much more likely to live in central cities, and, naturally, are far more likely to be immigrants and to speak English poorly ("not at all" or “not well”).

Next, we report on job density, in three consecutive panels. These panels are a bit complicated because they vary across three dimensions. First, down the rows of each panel we report the densities constructed the three different ways noted earlier: for overall jobs per resident, male jobs per male resident, and Hispanic and white male jobs per Hispanic and white male resident. In each of these cases we report job densities for both whites and Hispanics. Second, as we move across the columns of each panel we vary the sample over which the mean densities are reported. And third, each panel uses a different sample of workers to construct the density - for example, all workers are used in constructing the statistics in Panel B but only poor English speakers are used in Panel D. ${ }^{17}$

What does the table show? In column (1) of Panel B, when we compute densities over all Hispanics and whites, we find that, for each of the density measures used, Hispanics face job densities quite similar to or slightly below those faced by whites. In column (2), we vary the sample but use the same density measure, and we find that, for immigrants, job density is higher for Hispanics than for whites, but only by about .02 to $.05 .{ }^{18}$ In contrast, in column (3) we show that for those who speak poor English the pattern varies quite a bit with the density measure. However, we do not regard these latter Hispanic-white comparisons as very meaningful, given that the group of whites who speak English poorly is a very heterogeneous group of immigrants from very different places.

When we instead define job density only in terms of immigrants or poor English speakers, in Panels C and D, we find much sharper differences in jobs densities faced by Hispanics and whites, and in particular much lower densities faced by Hispanics. Moreover, the same holds true across the columns,

\footnotetext{
${ }^{17}$ To provide a few of concrete examples, then, the .72 number in the upper left-hand corner of Panel B is generated by calculating the mean over the entire Hispanic (male) sample of the number of jobs per resident in each Hispanic individual's zip-code area. The .74 number in the upper right-hand corner of Panel B is the mean across poor-Englishspeaking Hispanics of the same density measure. And the .71 number in the second row of the last column of Panel D is the mean of the number of jobs held by those who speak poor English divided by the number of residents who speak poor English, calculated over all whites who speak good English.
} 
when we restrict the sample over which the mean densities are computed. For immigrants, the Hispanicwhite differences are a bit smaller, and the mean densities for Hispanic immigrants are similar to the full sample (Panel C, column (2) versus column (1)). In contrast, for poor English speakers the Hispanic-white differences are about the same across columns (1) and (2) of Panel D, although the mean densities are lower for poor English speakers.

Overall, these descriptive statistics imply that Hispanics, on average, live in places that are slightly less dense in jobs (Panel B, column (1)), but in places in which there are substantially fewer jobs held by immigrants or poor English speakers per immigrant or poor-English-speaking resident (Panels C and D, column (1)). Moreover, Hispanics who speak poor English are not concentrated in places dense in jobs held by poor English speakers; in fact the opposite is more the case, as they face lower job densities defined for poor English speakers (Panel D, columns (2) and (3)).

With reference to the spatial mismatch hypothesis, the figures in Panel B contradict its basic tenet that Hispanics tend to live in areas less dense in jobs. However, this changes once we define job density by skill level, as Hispanics, who are more likely themselves to be low-skilled (in the sense of being immigrants or speaking English poorly), face lower ratios of low-skilled jobs to low-skilled residents than do whites.

Table 3 turns to ethnicity-specific job density measures. The structure of the three panels corresponds exactly to Panels B-D in Table 2 in terms of the samples and who is used to construct the density measures. However, now the densities are reported only for Hispanic men. Most important, though, Table 3 breaks out the density measures by ethnicity, with various versions of non-Hispanic jobs per Hispanic resident and Hispanic jobs per Hispanic resident reported.

As we would expect given the small share of the Hispanic population, on average Hispanics are exposed to a much higher white or non-Hispanic job density than Hispanic job density. For example, in Panel A, the mean of overall non-Hispanic jobs per Hispanic resident is 5.18, versus a mean of Hispanic

\footnotetext{
${ }^{18}$ Results were similar using all non-Hispanics, or just whites.
} 
jobs per Hispanic resident of .59. The comparisons are similar for immigrants and poor English speakers. The high value of non-Hispanic or white job density for Hispanics indicates that whites often hold many jobs in areas where Hispanics live.

The much higher non-Hispanic job density does not necessarily imply, however, that there are many jobs available to all Hispanics, regardless of their skill level, in the areas in which they live. It may be the case that the jobs available to Hispanics are primarily available only to non-immigrant Hispanics (42 percent of Hispanic men in our sample) or to Hispanics who speak good English (72 percent of Hispanic men). It is of interest, then, to compare the ethnicity-specific job density measures constructed using only immigrants or only poor English speakers, which we do in Panels B and C of Table 3. The differences between non-Hispanic and Hispanic job density faced by Hispanics fall sharply, and are even reversed in some cases. This in fact is not surprising, since there are not that many immigrants or poor English speakers who are non-Hispanic or white. This is quite a bit different from the results for blacks reported in Hellerstein et al. (2008a), where we looked at job densities defined by education level, and still found that less-educated blacks live in areas where there are many more jobs held by less-educated whites than by less-educated blacks. Of course, education does less to separate blacks from whites than immigrant status and language skills do to separate Hispanics from non-Hispanics.

\section{Regression Results}

We now turn to the regression results, beginning with the simple spatial mismatch specifications in which we do not define job density based on ethnicity. We first report estimates of equations (1)-(4), which include overall job density measures or these measures defined for poor English speakers, but without distinguishing the density measures by ethnicity. The top panel of Table 4 reports estimates of equations (1) and (3), using a single job density measure with no interactions with the individual's language or immigrant status. If spatial mismatch is important, it suggests in particular that job density defined for lower skill levels - such as poor English speakers - should increase the probability of employment for Hispanics, of whom many are low skilled. The estimates in the top row of Table 4 are consistent with this. There is either an insignificant or at least very small effect of overall job density on Hispanic employment, as shown in 
each of the odd-numbered columns of the table. However, when we define job density by dividing jobs held by poor English speakers by poor-English-speaking residents, in the even-numbered columns (corresponding to equation (3)), there is a much larger and statistically significant positive effect of job density. ${ }^{19}$ The effect is not large, however. For example, the estimate of .024 in column (4) implies that a 0.1 (or 10 percentage point) increase in job density for poor English speakers raises the probability of employment by .0024 , or about 0.4 percent given the mean employment rate for Hispanic men of .61.

The bottom panel of Table 4 reports estimates of equations (2) and (4), where we estimate separate effects of job density for Hispanic poor English speakers and good English speakers. The spatial mismatch hypothesis predicts that job density should matter more for poor English speakers, and that this should be particularly true when job density is measured based on those who speak English poorly. The point estimates are largely consistent with these expectations. In each of the even-numbered columns, where job density is defined based on poor English speakers, we find a positive effect of job density on employment, and this effect is always larger for poor English speakers (e.g., .061 versus .031 in column (2)); the differences between the estimates in the last two rows are always statistically significant. ${ }^{20}$

We next explore whether the ethnic composition of the jobs available to residents is important. To begin, columns (1), (3), and (5) of the top panel of Table 5 report estimates of equation (1'), where we simply use a measure of overall job density (not distinguished by language skills), although broken down

\footnotetext{
${ }^{19}$ Most of our key results are strongly statistically significant, so in the ensuing discussion we often avoid continually referring to the statistical significance of the results.

${ }^{20}$ It is possible that because of endogenous sorting employment rates are higher in areas in which residents are more employable based on a set of unobserved person-specific characteristics, so that the relationship between job density and employment need not reflect spatial mismatch. While we obviously cannot control for all characteristics of workers, given that we are able to control for some key ones, we are more inclined to interpret the variation in job densities as reflecting some kind of spatial influences. In addition, echoing the argument made earlier, the evidence of stronger effects of the spatial distribution of jobs for poor English speakers is an implication of the spatial mismatch model that does not derive nearly as naturally from the hypothesis of unobserved characteristics, given that there is no obvious reason that job density should serve as a stronger proxy for these unobservables for those with fewer skills relative to those with more skills.
} 
by ethnicity. ${ }^{21}$ The estimates in these three columns indicate very clearly that only job density for Hispanics is substantively related to the employment of Hispanics. In each case, the estimated coefficient on the Hispanic job density measure is much larger than that of the non-Hispanic job density measure, by a factor of about 20. Next, we instead measure job density based on poor English speakers, reporting results in columns (2), (4), and (6). These results are similar. The estimated effects of non-Hispanic job density are very small, and insignificant in one case, while the estimated effects of Hispanic job density are much larger.

In the bottom panel of Table 5, we present evidence on the impact of ethnicity-specific job density on the employment of Hispanics who speak English poorly and who speak English well, corresponding to equations (2') and (4'). As in the top panel, non-Hispanic job density has only a very small effect on Hispanic employment, and this is true whether or not we define the density measures for poor English speakers, and whether we look at poor English speakers or good English speakers. In contrast, Hispanic job density has strong effects on employment. Moreover, Hispanic job density is particularly important for the employment of Hispanics who speak English poorly, and more so when we define job density based on poor English speakers. In the odd-numbered columns, with the broad job density measure, the effect of Hispanic job density on poor English speakers is about 1.4 times the effect on good English speakers. But in the even-numbered columns, defining density over poor English speakers, this ratio ranges from 2.7 to 3.2. ${ }^{22}$

Tables 6 and 7 present evidence parallel to that in Tables 4 and 5, but distinguishing workers by immigrant status rather than English-language skills. As in Table 4, in Table 6 we use job density measures that do not distinguish by ethnicity. In the even-numbered columns, though, we report results using job

\footnotetext{
${ }^{21}$ Note that, relative to the job density measures in Table 4, these density measures utilize a different denominator defined only by Hispanic residents. We do this to isolate the role of job availability for Hispanic residents, rather than for all residents. As a result, the scale of the density measures in Table 5 is much larger than in Table 4 (see the summary statistics in Tables 2 and 3), which can affect the scale of the estimated regression coefficients in Table 5 relative to Table 4, irrespective of whether the effects of Hispanic job density and non-Hispanic job density differ.

${ }^{22}$ The estimated effects of Hispanic job density, in both panels, are a bit larger if we exclude the MSA fixed effects from the specifications in Table 5, but the qualitative conclusions are the same. The estimates were insensitive to excluding the central city, non-central city, and suburban controls.
} 
density defined only for immigrants, and in the lower panel we report the estimated coefficients of interactions between job density and immigrant status. Then, in Table 7 we also break up the job density measures by Hispanic ethnicity. The top panel of Table 6 shows that job density is an important determinant of Hispanic employment when it is defined for immigrants (even-numbered columns), although this relationship is a bit weaker than for job density defined for poor English speakers (Table 4). In addition, this density measure is more important for immigrants, as shown in the bottom panel of Table 6, although in contrast to the distinction based on language skills (bottom panel of Table 4), in this case the differences are not large (and generally not statistically significant).

Breaking up the job density measures by ethnicity, in Table 7, it is principally Hispanic job density that matters for Hispanic employment, as shown in the top panel of the table. However, in contrast to Table 5, the estimated effects of Hispanic job density - defined only for immigrants - remain about as large as the estimated effects of Hispanic job density defined for all Hispanics, perhaps because immigrant status, per se, is not a strong indicator of skill once one conditions on ethnicity. In the bottom panel of Table 7, we find, as in the top panel, that non-Hispanic job density has only a very small effect on Hispanic employment, whether or not we define job density for immigrants only. Again, Hispanic job density drives Hispanic employment. However, the one difference compared to Table 5 is that the effects of Hispanic job density for immigrants are about the same size as for non-immigrants (and actually a shade smaller), implying that the effect of Hispanic job density on employment of Hispanics is not strongly related to immigrant status. This could be because, as suggested above, immigrant status is not as strongly related to skill (for Hispanics) as is poor English.

Labor market discrimination at a local level could give rise to a finding that Hispanics tend to be employed when they live in areas where many other Hispanics hold jobs, but not when they live in areas where many non-Hispanics are employed. For example, in the Becker model (1971) of employer or employee discrimination, if the distribution of discriminatory employers or employees varies across areas, 
then this variation in Hispanic employment could arise. ${ }^{23}$ Yet when we estimate similar "racial mismatch" specifications for white males, a group for which discrimination should not be much of an issue, we find very similar findings. In Table 8 we report estimates of employment equations for whites, paralleling those in Tables 5 and 7, and here restricting attention to males. We define density overall, and for skill groups defined by schooling level, and we estimate separate effects of job density by schooling (paralleling what we did earlier with poor English skills and immigrant status). The results clearly indicate that it is white job density only that is associated with increases in white employment, ${ }^{24}$ and that the relationship is stronger when density is defined over those with less education and when we estimate effects for those with less education.

In our view, the fact that we get similar types of findings for whites as well as Hispanics (and for blacks, as reported in our other work), suggests that racially- and ethnically-stratified networks rather than discrimination explain the results, although we cannot decisively rule out co-worker discrimination on the part of each racial or ethnic group against other groups. Just as with lower-skilled Hispanics, to the extent that the type of network effect detected by these regressions is based geographic proximity, we would expect stronger network effects for lower-skilled whites (and blacks) as well, as labor markets for lessskilled workers are more local and hence local networks should play a larger role.

Thus, in our view, the most plausible explanation of the results for Hispanics that we have presented thus far is that labor market networks are important in securing employment for those whose language skills (and ethnicity generally) make it difficult to productively navigate traditional avenues for finding employment. In the next section we try to provide further evidence on the importance of networks for Hispanics.

\section{Interpretation: Networks?}

The evidence thus far indicates that spatial mismatch alone is not a good characterization of the

\footnotetext{
${ }^{23}$ Formally, the employer discrimination model gives rise to wage differentials rather than employment differentials. But with different assumptions on the nature of discriminatory tastes than are typical in the Becker model, more discriminatory employers will hire fewer Hispanic workers (see, e.g., Hellerstein and Neumark, 2006).
} 
relationship between job density and Hispanic employment. It is true that the job density of lower-skilled groups - especially those who speak English poorly - matters more for the employment of Hispanics, and especially for the employment of less-skilled Hispanics; both of these results are implied by the usual spatial mismatch hypothesis. But in contrast to the predictions of the spatial mismatch hypothesis, and more consistent with our past finding of “racial mismatch" for blacks (and for whites), we find that Hispanic employment is much more strongly tied to the density of jobs held by Hispanics (and is essentially unrelated to non-Hispanic job density).

The dependence of employment on own-ethnicity job density could be due to a number of factors, but one factor that we believe is likely to be important is labor market networks. Indeed, as mentioned previously, evidence that we describe in Hellerstein et al. (2008b) points quite strongly to the importance of labor market networks for Hispanics, and especially for Hispanic immigrants and Hispanics who speak English poorly. This should not be surprising. Immigrants may suffer from high search costs in the labor market, both because their limited understanding of U.S. labor markets and of English may make it hard for them to search widely in the labor market, and firm-side search frictions are likely to be important because employers may have a difficult time inferring the ability of these workers. Finding employment through informal networks of other immigrants and those who speak one's native language may therefore be particularly important for these groups.

There is a fair amount of other evidence consistent with this hypothesis. First, survey evidence indicates that Hispanics use referrals in finding employment much more than do blacks or whites (Ioannides and Datcher Loury, 2004). There is also evidence of “enclave effects," such as the finding that Hispanics with poor English skills pay less of a penalty for those poor skills when they live in a county or MSA with a larger Hispanic population (McManus, 1990); this could reflect network effects, although it could also reflect higher productivity from a greater ability to work with Spanish speakers in the enclave. ${ }^{25}$

\footnotetext{
${ }^{24}$ It is possible that the negative coefficient estimates for non-white density can be explained by low unobservables related to employment for whites living in areas of high non-white job density (conditional on white job density).

${ }^{25}$ For a similar type of evidence for Sweden, see Edin et al. (2003). For recent evidence for Denmark, see Piil Damm (2009).
} 
Munshi (2003) presents a more-refined analysis of Mexican immigrants, tying labor market outcomes to a larger local population of immigrants from the same origin community. Patel and Vella (2007) find that new immigrants work disproportionately in occupations held by previous immigrants from the same country. And our previous work documents establishment-level segregation by English language skills, and segregation of Spanish-speaking from non-Spanish speaking poor English speakers (Hellerstein and Neumark, 2008), as well as evidence of strong residence-based networks among low-skilled Hispanics (Hellerstein et al., 2008b). Finally, perhaps the most direct evidence of these types of networks for immigrants comes from the work of Massey et al. (1987), who document through both survey and case study evidence the importance of networks linking recent and earlier immigrants from the same communities in Mexico.

Our final analysis asks whether network effects likely underlie the type of evidence we have reported thus far. As argued earlier, cities in which there has been recent rapid growth of the Hispanic immigrant population are likely to be places in which networks are particularly important in securing employment. One might argue that networks will be more pervasive in areas that have long had a large Hispanic immigrant presence. No doubt, in absolute terms, there is some validity to this. But it seems likely that in Los Angeles, for example, a Mexican immigrant (perhaps with the exception of a new arrival) does not need to rely on a network to find a job. There are many, many jobs available, and Los Angeles employers presumably know how to evaluate the abilities of these workers. In contrast, an employer in Greensboro who has hired only a few Hispanic immigrants may need to rely heavily on those employees to screen new Hispanic workers, and indeed to recruit them by spreading the word back in their countries of origin (or communities elsewhere in the United States) about the availability of jobs in Greensboro. We therefore report estimates for sets of these metropolitan areas - in particular, for the top 50, 30, and 10 metropolitan areas in terms of the rate of growth between 1990 and 2000 of the non-native Hispanic working-age male population. These cities and their growth rates are displayed in Appendix Table A1.

In particular, we estimate the specification from column (1) of Table 5, including the specification in the lower panel of the table, where the effects of job density differ for those with poor English. We use 
the aggregate job density measures defined for either all Hispanic or all non-Hispanic workers rather than the measure defined for poor English speakers alone because networks may well cross skill boundaries when workers are recruited or induced to move to new locales to find employment. Nonetheless, we would still expect both a priori and based on the preceding evidence that the effect of Hispanic job density is particularly pronounced for the poor English speakers for whom networks are likely to be most important.

The evidence, reported in Table 9 turns out to be quite consistent with the network interpretation. Relative to the baseline estimates in column (1), which repeat the earlier estimates (Table 5, column (1)) for the full sample, in the top panel the effects of Hispanic job density are quite a bit larger for the metropolitan areas with the highest Hispanic immigrant growth - especially the narrowest set of such MSAs (the top 10). Similarly, in the bottom panel we find that the effects of Hispanic job density for those who speak poor English are much stronger in the MSAs with high Hispanic immigrant growth, again most markedly for the top 10 cities. Finally, since networks are likely most important for those with poor English skills, one might argue that the difference between the effects of Hispanic job density for those with poor and good English skills should be largest where networks are the most important. The estimates in the last column, for the 10 cities with the fastest-growing Hispanic immigrant population, are consistent with this, although the pattern of coefficient estimates in the other columns is less clear.

One alternative to the network hypothesis in explaining why ethnic-specific job density matters more for the employment of Hispanics in new immigrant communities is the importance of language complementarities, where in a metropolitan area with few Spanish speakers, the local availability of jobs with other Spanish-speaking co-workers is essential to the employment of new immigrants. ${ }^{26}$ We cannot rule out this possibility entirely, but it seems unlikely that new Hispanic immigrants, who largely speak English poorly, began migrating in large numbers to areas with few Hispanics in order to take advantage of such complementarities, because there have to be far more opportunities to find businesses with Spanish-

\footnotetext{
${ }^{26}$ Lazear (1999) formalizes this in a model where a common language lowers transaction costs across workers within a firm and across firms that trade (with other firms or with customers). In his model it is therefore efficient (at least in a static model) for workers to be grouped with others who speak the same language, thereby making it easier for Hispanics with poor English proficiency to find work if they live near jobs held by other Spanish speakers.
} 
speaking workforces (and owners) in Los Angeles. ${ }^{27}$

It is also possible that the findings in Table 9 are demand-driven, with the cross-city variation in the growth rate of the non-U.S. born Hispanic population reflecting variation in industries that tend to hire low-skill Hispanics. To assess this story, we re-estimated the specifications in Table 9 defining job density for poor English speakers (i.e., restricting the numerator and denominator of the job density measure to poor English speakers). If the results in Table 9 are driven by faster growth of jobs employing less-skilled Hispanics, then when we define job density for poor English speakers the patterns in Table 9 - suggesting stronger effects of Hispanic job density in the cities with the fastest growth of the non-native Hispanic population - should be more marked. In fact, we find that they are not. When we define job density based on poor English speakers, there is not a very clear pattern of stronger effects of Hispanic job density for cities with the fastest growth, although the effects are strongest for the top-10 cities. ${ }^{28}$ In contrast, the evidence that the relationship between the effects of Hispanic job density on Hispanic employment, and the growth rate of the non-native Hispanic population, is strongest when we define Hispanic job density for all Hispanics is more consistent with our network interpretation whereby networks cross skill boundaries among Hispanics, but nonetheless are particularly beneficial to less-skilled Hispanics for whom, because of recent migration of Hispanic immigrants, information on both sides of the labor market is likely to be worse. $^{29}$

\section{$\underline{\text { VI. Conclusions }}$}

There is little previous evidence on the importance of the location of job access for the employment prospects of Hispanics in the United States, and virtually no national evidence on the importance of very localized measures of job density. This is a particularly important issue given that Hispanic employment

\footnotetext{
${ }^{27}$ In addition, the existence of language complementarities is a less compelling explanation in our view, for the similar racial/ethnic mismatch findings for whites and blacks that parallel those that we find here for Hispanics.

${ }^{28}$ The full results are shown in Appendix Table A2.
} 
rates in the United States are well below those of whites, and because Hispanics are the fastest-growing segment of the U.S. population.

We take advantage of confidential access to all respondents to the 2000 Decennial Census LongForm to study the relationship between Hispanic employment and location-specific measures of the distribution of jobs, with special focus on Hispanics who speak English poorly. We find evidence consistent with a spatial mismatch hypothesis where local job density is skill-based. However, it turns out that it is only the density of jobs held by Hispanics that matters for Hispanic employment. We also find that measures of local job density defined for Hispanic poor English speakers or immigrants are strongly positively related to Hispanic employment for residents of those areas. Moreover, the measures of the density of jobs held by Hispanic poor English speakers are more important for the employment of these less-skilled Hispanics than for other Hispanics.

We have suggested that the evidence that overall job density has little effect on Hispanic employment, but ethnic-specific job density does matter, especially for poor English speakers, is consistent with the labor market networks being an important influence on the employment of less-skilled Hispanics. To provide further evidence on whether networks are important, and, if so, to begin to understand the underlying mechanism for these results, we present results that disaggregate the effects of job density on Hispanic employment across metropolitan areas that have experienced differential rates of growth of the non-native Hispanic population over the decade of the 1990s. We find that in MSAs where the growth rates of the immigrant population have been highest, which are also MSAs with historically low Hispanic populations, localized job density for low-skilled jobs is even more important for Hispanic employment than in the full sample. We interpret these results as consistent with the importance of labor market networks, as strong labor market networks are likely to have been especially important in inducing

\footnotetext{
${ }^{29}$ Finally, the results in this section are also potentially consistent with discrimination, to the extent that in new immigrant metro areas, there may be more discriminatory employers, so that it is especially important for poor English speakers to live near employers who, evidenced by their hiring of other Hispanics with poor English skills, do not discriminate. Once again, though, we view this explanation as less likely than a one based on networks given that overall we have found results for the importance of own-race and own-ethnicity density on employment to exist for Hispanics, blacks, and whites, and to be especially important for low-skilled workers within each of these groups.
} 
Hispanics to migrate, and because of these networks employment in these "new immigrant" cities is then especially strongly tied to the local availability of jobs. This evidence is also complementary to other research we have done documenting the importance of labor market networks for Hispanics in the U.S. labor market (Hellerstein et al., 2008b; Hellerstein and Neumark, 2008).

Finally, we return to the possible policy implications of our findings. The spatial mismatch hypothesis - whether applied to blacks and Hispanics in the United States or other ethnic or racial groups in Europe - implies that part of the solution to increasing employment of these groups involves better access to jobs, whether by moving people to jobs or by moving jobs to people. But the evidence we have presented in this paper and our other papers, for both Hispanics and blacks, suggests that labor market networks are quite important. Moreover, labor market networks may provide a better explanation of the positive relationship between the job density in a neighborhood and the employment rates of disadvantaged groups residing there - a relationship that, on the surface, might be viewed as supportive of the spatial mismatch hypothesis. The key policy implication is that if networks are important, then location-based policies moving disadvantaged residents to areas more dense in jobs, increasing their transportation access to those areas, or establishing incentives to create jobs in the areas where they currently live - are likely to prove less effective than would be suggested by the simple relationship between employment and job density. And policies like moving residents to other locations, which may sever network connections, may prove completely ineffective or even counterproductive. 


\section{References}

Becker, Gary S. 1971. The Economics of Discrimination, $2^{\text {nd }}$ edition (Chicago: University of Chicago Press).

Blumenberg, Evelyn, and Paul Ong. 1998. "Job Accessibility and Welfare Usage: Evidence from Los Angeles.” Journal of Policy Analysis and Management, Vol. 17, No. 4, pp. 639-57.

Card, David, 1990. “The Impact of the Mariel Boatlift on the Miami Labor Market.” Industrial and Labor Relations Review, Vol. 43, No. 2, January, pp. 245-57.

Card, David and Ethan G. Lewis. 2007. "The Diffusion of Mexican Immigrants During the 1990s:

Explanations and Impacts.” In Mexican Immigration to the United States, ed. George J. Borjas (Chicago:

University of Chicago Press), pp.193-227.

Cutler, David M., and Edward L. Glaeser. 1997. “Are Ghettos Good or Bad?” Quarterly Journal of Economics, Vol. 112, No. 3, August, pp. 827-72.

Drever, Anita I., and William A. V. Clark. 2006. "Mixed Neighborhoods, Parallel Lives? Residential Proximity and Inter-Ethnic Group Contact in German Neighborhoods.” Unpublished paper, University of Tennessee.

Edin, Pers-Anders, Peter Fredriksson, and Olof Åslund. 2003. "Ethnic Enclaves and the Economic Success of Immigrants - Evidence from a Natural Experiment.” Quarterly Journal of Economics, Vol. 118, No. 1, February, pp. 329-57.

Ellis, Mark, Richard Wright, and Virginia Parks. 2007. "Geography and the Immigrant Division of Labor.” Economic Geography, Vol. 83, No. 3, pp. 255-82.

Ellwood, David. 1986. “The Spatial Mismatch Hypothesis: Are There Jobs Missing in the Ghetto?” In The Black Youth Employment Crisis, eds. Freeman and Holzer (Chicago: University of Chicago Press), pp. 147-85.

Farley, John. 1987. "Disproportionate Black and Hispanic Unemployment in US Metropolitan Areas.” American Journal of Economics and Sociology, Vol. 46, No. 2, pp. 129-50.

Fernandez, Roberto M. 2008. "Race, Spatial Mismatch, and Job Accessibility: Evidence from a Plant Relocation.” Social Science Research, Vol. 37, No. 3, pp. 953-75.

Gobillon, Laurent, and Harris Selod. 2007. "The Effects of Segregation and Spatial Mismatch on Unemployment: Evidence from France.” INRA Laboratoire d’Economie Appliquee Working Paper 0702.

Goldberg, Heidi. 2001. "State and County Supported Car Ownership Programs Can Help Low-Income Families Secure and Keep Jobs.” Center on Budget and Policy Priorities, November 28, available at http://www.cbpp.org/11-8-01wel.htm (as of October 28, 2005).

Harrison, Bennett. 1972. “The Intrametropolitan Distribution of Minority Economic Welfare.” Journal of Regional Science, Vol. 12, No. 1, pp. 23-43.

Hellerstein, Judith K., and David Neumark. 2006. "Using Matched Employer-Employee Data to Study Labor Market Discrimination.” In Handbook on the Economics of Discrimination, ed. William M. Rodgers 
III (Cheltenham, U.K.: Edward Elgar), pp. 29-60.

Hellerstein, Judith K., and David Neumark. 2008. "Workplace Segregation in the United States: Race, Ethnicity, and Skill.” Review of Economics and Statistics, Vol. 90, No. 3, pp. 459-77.

Hellerstein, Judith K., David Neumark, and Melissa McInerney. 2008a. "Spatial Mismatch vs. Racial Mismatch?” Journal of Urban Economics, Vol. 64, No. 2, pp. 467-79.

Hellerstein, Judith K., David Neumark, and Melissa McInerney. 2008b. "Measuring the Importance of Labor Market Networks.” NBER Working Paper No. 14201.

Hillman, Felicitas. 2002. “A Look at the 'Hidden Side': Turkish Women in Berlin's Ethnic Labour Market.” International Journal of Urban and Regional Research, Vol. 23, No. 2, pp. 267-82.

Holzer, Harry J. 1991. “The Spatial Mismatch Hypothesis: What Has the Evidence Shown?” Urban Studies, Vol. 28, No. 1, February, pp. 105-22.

Ihlanfeldt, Keith R. 1992. Job Accessibility and the Employment and School Enrollment of Teenagers (Kalamazoo, MI: W. E. Upjohn Institute for Employment Research).

Ihlanfeldt, Keith R., and David Sjoquist. 1990. "Job Accessibility and Racial Differences in Youth Employment Rates.” American Economic Review, Vol. 80, No. 1, pp. 267-76.

Ihlanfeldt, Keith R., and David Sjoquist. 1998. “The Spatial Mismatch Hypothesis: A Review of Recent Studies and Their Implications for Welfare Reform.” Housing Policy Debate, Vol. 8, No. 4, pp. 849-92.

Ioannides, Yannis M., and Linda Datcher Loury. 2004. “Job Information, Networks, Neighborhood Effects, and Inequality.” Journal of Economic Literature, Vol. 42, No. 4, pp. 1056-93.

Kain, John. 1992. “The Spatial Mismatch Hypothesis: Three Decades Later.” Housing Policy Debate, Vol. 3, No. 2, pp. 371-92.

Kain, John. 1968. “Housing Segregation, Negro Employment, and Metropolitan Decentralization.” Quarterly Journal of Economics, Vol. 82, No. 2, pp. 175-97.

Kastoryano, Riva, and Barbara Harshav. 2002. Negotiating Identities (Princeton, NJ: Princeton University Press).

Katz, Lawrence F., Jeffrey R. Kling, and Jeffrey B. Liebman. 2001. "Moving to Opportunity in Boston: Early Results of a Randomized Mobility Experiment.” Quarterly Journal of Economics, Vol. 116, No. 2, pp. 607-54.

LaFortune, Jeanne. 2008. "Making Yourself Attractive: Pre-Marital Investments and the Returns to Education in the Marriage Market.” Unpublished paper, University of Maryland.

Lazear, Edward P. 1999. “Culture and Language.” Journal of Political Economy, Vol. 107, No. S6, pp. S95-126.

Manski, Charles. 1993. “Identification of Endogenous Social Effects: The Reflection Problem.” Review of Economic Studies, Vol. 60, No. 3, pp. 531-42.

Massey, Douglas, Rafael Alarcón, Jorge Durand, and Humberto González. 1987. Return to Aztlan: The 


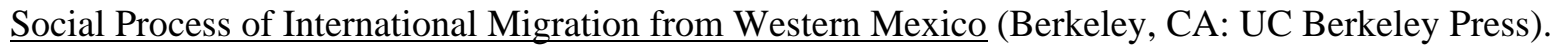

McLafferty, Sara, and Valerie Preston. 1996. "Spatial Mismatch and Employment in a Decade of Restructuring.” Professional Geographer, Vol. 48, No. 4, pp. 417-67.

McLafferty, Sara, and Valerie Preston. 1992. "Spatial Mismatch and Labor Market Segmentation for African American and Latina Women.” Economic Geography, Vol. 68, No. 4, pp. 406-31.

McManus, Walter S. 1990. "Labor Market Effects of Language Enclaves: Hispanic Men in the United States.” Journal of Human Resources, Vol. 25, No. 2, pp. 228-52.

Montgomery, James D. 1991. "Social Networks and Labor-Market Outcomes: Toward an Economic Analysis.” American Economic Review, Vol. 81, No. 5, pp. 1408-18.

Munshi, Kaivan. 2003. "Networks in the Modern Economy: Mexican Migrants in the U.S. Labor Market.” Quarterly Journal of Economics, Vol. 118, No. 2, pp. 549-99.

Patel, Krishna, and Francis Vella. 2007. "Immigrant Networks and Their Implication for Occupational Choices and Wages.” IZA Working Paper No. 3217.

Piil Damm, Anna. 2009. "Ethnic Enclaves and Immigrant Labor Market Outcomes: Quasi-Experimental Evidence.” Journal of Labor Economics, Vol. 27, No. 2, pp. 281-314.

Price, Richard, and Edwin Mills. 1985. "Race and Residence in Earnings Determination.” Journal of Urban Economics, Vol. 17, No. 1, pp. 1-18.

Raphael, Steven. 1998. "The Spatial Mismatch Hypothesis of Black Youth Joblessness: Evidence from the San Francisco Bay Area.” Journal of Urban Economics, Vol. 43, No. 1, January, pp. 79-111.

Ross, Stephen L. 1998. "Racial Differences in Residential and Job Mobility: Evidence Concerning the Spatial Mismatch Hypothesis.” Journal of Urban Economics, Vol. 43, No. 1, pp. 112-35.

Schönwälder, Karen, ed. 2007. "Residential Segregation and the Integration of Immigrants: Britain, the Netherlands and Sweden.” WZB Discussion Paper No. SP IV 2007-602.

Taylor, D. Brian, and Paul M. Ong. 1995. "Spatial Mismatch or Automobile Mismatch? An Examination of Race, Residence and Commuting in U.S. Metropolitan Areas.” Urban Studies, Vol. 32, No. 9, pp. 1453-73.

Thompson, Mark A. 1997. "The Impact of Spatial Mismatch on Female Labor Force Participation.” Economic Development Quarterly, Vol. 11, No. 2, pp. 138-45.

Vrooman, John, and Stuart Greenfield. 1980. “Are Blacks Making It in the Suburbs? Some New Evidence on Intrametropolitan Spatial Segmentation.” Journal of Urban Economics, Vol. 7, No. 2, pp. 155-67.

Weinberg, Bruce. 2004. "Testing the Spatial Mismatch Hypothesis Using Inter-City Variations in Industrial Composition.” Regional Science and Urban Economics, Vol. 34, No. 5, pp. 505-32.

Zenou, Yves, Olof Åslund, and John Östh. 2006. "How Important is Access to Jobs? Old Question Improved Answer.” IZA Discussion Paper No. 2051. 
Table 1: SEDF Sample

\begin{tabular}{lcc}
\hline & $(1)$ & $(2)$ \\
\hline Full SEDF (not institutionalized) & Total & $\begin{array}{c}\text { Hispanic } \\
\text { males }\end{array}$ \\
Restrict to men & $42,583,178$ & $\ldots$ \\
Exclusion criteria (total cases): & $20,713,501$ & $2,329,920$ \\
Not in CMSA/MSA & & \\
Not in age range 16-64 & $\ldots$ & 285,876 \\
In military & $\ldots$ & 862,899 \\
Enrolled in school & $\ldots$ & 6,872 \\
Work limiting disability & $\ldots$ & 907,490 \\
SEDF observations retained & $\ldots$ & 300,266 \\
Live in water zip & $\ldots$ & $\mathbf{8 6 5 , 3 5 4}$ \\
Work in water zip & $\ldots$ & 4,484 \\
Observations with unmatched or allocated place of & $\ldots$ & 2,783 \\
work location & $\ldots$ & 227,266 \\
Total observations remaining for calculation of & $\ldots$ & 631,027 \\
densities & & \\
Observations dropped because of undefined & $\ldots$ & 5,504 \\
density or missing zip code & & $\mathbf{6 2 5 , 5 2 3}$ \\
Final sample & $\ldots$ & \\
\hline
\end{tabular}

SEDF: Sample Edited Detail File of all Long-Form Census respondents. The exclusion criteria are not mutually exclusive, so many observations show up in multiple rows. 
Table 2: Comparisons of Individual Characteristics and Overall Job Density Measures by Ethnicity

\begin{tabular}{|c|c|c|c|}
\hline & $(1)$ & $(2)$ & (3) \\
\hline A. Individual characteristics (means): & Hispanic men & Non-Hispanic & White men \\
\hline Employment & .61 & .79 & .83 \\
\hline \multicolumn{4}{|l|}{ Individual characteristics: } \\
\hline Central city & .50 & .23 & .29 \\
\hline Immigrant & .58 & .10 & .05 \\
\hline Speak English not at all & .098 & .002 & .001 \\
\hline Speak English not well & .182 & .014 & .007 \\
\hline Speak English well & .190 & .025 & .012 \\
\hline \multirow[t]{2}{*}{ Speak English very well } & .531 & .960 & .981 \\
\hline & \multicolumn{3}{|c|}{ Sample } \\
\hline B. Job density constructed using all jobs and all residents & All & Immigrants & Poor English \\
\hline \multicolumn{4}{|l|}{ Jobs/residents } \\
\hline Hispanics & $.72(.41)$ & $.72(.41)$ & $.74(.41)$ \\
\hline Whites & $.75(.41)$ & $.67(.39)$ & $.71(.57)$ \\
\hline \multicolumn{4}{|l|}{ Male jobs/male resident } \\
\hline Hispanics & $.81(.46)$ & $.83(.45)$ & $.84(.46)$ \\
\hline Whites & $.82(.46)$ & $.81(.47)$ & $.94(.87)$ \\
\hline \multicolumn{4}{|l|}{ Hispanic and white male jobs/Hispanic and white male } \\
\hline Hispanics & $.85(.53)$ & $.86(.52)$ & $.88(.54)$ \\
\hline Whites & $.85(.54)$ & $.82(.47)$ & $1.01(1.08)$ \\
\hline C. Job density constructed using immigrants & All & Immigrants & Non-Immigrants \\
\hline \multicolumn{4}{|l|}{ Jobs/residents } \\
\hline Hispanics & $.58(.33)$ & $.57(.31)$ & $.59(.35)$ \\
\hline Whites & $.80(.53)$ & $.71(.55)$ & $.72(.79)$ \\
\hline \multicolumn{4}{|l|}{ Male jobs/male resident } \\
\hline Hispanics & $.70(.38)$ & $.68(.36)$ & $.71(.41)$ \\
\hline Whites & $.89(.60)$ & $.83(.63)$ & $.97(1.16)$ \\
\hline \multicolumn{4}{|l|}{ Hispanic and white male jobs/Hispanic and white male } \\
\hline Hispanics & $.69(.39)$ & $.67(.36)$ & $.72(.42)$ \\
\hline Whites & $.92(.64)$ & $.84(.58)$ & $1.08(1.46)$ \\
\hline D. Job density constructed using poor English speakers & All & Poor English & Good English \\
\hline \multicolumn{4}{|l|}{ Jobs/residents } \\
\hline Hispanics & $.50(.39)$ & $.47(.28)$ & $.51(.42)$ \\
\hline Whites & $.75(.40)$ & $.67(.38)$ & $.71(.56)$ \\
\hline \multicolumn{4}{|l|}{ Male jobs/male resident } \\
\hline Hispanics & $.67(.56)$ & $.61(.39)$ & $.69(.61)$ \\
\hline Whites & $.82(.45)$ & $.80(.46)$ & $.93(.85)$ \\
\hline \multicolumn{4}{|l|}{ Hispanic and white male jobs/Hispanic and white male } \\
\hline Hispanics & $.69(.68)$ & $.62(.44)$ & $.72(.75)$ \\
\hline Whites & $.84(.53)$ & $.82(.46)$ & $1.01(1.06)$ \\
\hline
\end{tabular}

Standard deviations (SD) of continuous variables are reported in parentheses in Panels B through D. All estimates are weighted to account for differences in the probability of having valid place of work data. "Poor English" refers to the bottom two categories, and "Good English" to the other two. 
Table 3: Ethnicity-Specific Job Density Measures for Hispanic Men

\begin{tabular}{|c|c|c|c|}
\hline & (1) & $(2)$ & (3) \\
\hline & \multicolumn{3}{|c|}{ Sample } \\
\hline & All & Immigrants & Poor English \\
\hline \multicolumn{4}{|l|}{ A. Job density measures constructed for all } \\
\hline Non-Hispanic jobs/Hispanic residents & $5.18(11.86)$ & $4.68(10.83)$ & $4.45(9.86)$ \\
\hline $\begin{array}{l}\text { Non-Hispanic male jobs/Hispanic male } \\
\text { residents }\end{array}$ & $5.32(12.16)$ & $4.73(10.78)$ & $4.45(9.54)$ \\
\hline White male jobs/Hispanic male residents & $4.54(10.78)$ & $3.98(9.42)$ & $3.75(8.30)$ \\
\hline Hispanic jobs/Hispanic residents & $.59(.40)$ & $.58(.38)$ & $.56(.32)$ \\
\hline Hispanic male jobs/Hispanic male residents & $.69(.47)$ & $.68(.44)$ & $.66(.37)$ \\
\hline \multicolumn{4}{|l|}{$\begin{array}{l}\text { B. Job density measures constructed using } \\
\text { immigrants }\end{array}$} \\
\hline Non-Hispanic jobs/Hispanic residents & $.94(2.35)$ & $.75(1.77)$ & $.69(1.48)$ \\
\hline $\begin{array}{l}\text { Non-Hispanic male jobs/Hispanic male } \\
\text { residents }\end{array}$ & $.99(2.79)$ & $.79(2.17)$ & $.72(1.67)$ \\
\hline White male jobs/Hispanic male residents & $.46(1.50)$ & $.35(1.12)$ & $.32(.94)$ \\
\hline Hispanic jobs/Hispanic residents & $.57(.46)$ & $.55(.41)$ & $.53(.33)$ \\
\hline Hispanic male jobs/Hispanic male residents & $.71(.63)$ & $.68(.55)$ & $.65(.42)$ \\
\hline \multicolumn{4}{|l|}{$\begin{array}{l}\text { C. Job density measures constructed using } \\
\text { poor English speakers }\end{array}$} \\
\hline Non-Hispanic jobs/Hispanic residents & $.35(2.12)$ & $.26(1.25)$ & $.20(.73)$ \\
\hline $\begin{array}{l}\text { Non-Hispanic male jobs/Hispanic male } \\
\text { residents }\end{array}$ & $.39(2.45)$ & $.28(1.48)$ & $.21(.90)$ \\
\hline White male jobs/Hispanic male residents & $.15(.79)$ & $.11(.58)$ & $.09(.36)$ \\
\hline Hispanic jobs/Hispanic residents & $.55(.73)$ & $.51(.60)$ & $.48(.40)$ \\
\hline Hispanic male jobs/Hispanic male residents & $.75(1.27)$ & $.69(1.05)$ & $.63(.66)$ \\
\hline $\mathrm{N}$ & 625,523 & 360,453 & 175,019 \\
\hline
\end{tabular}


Table 4: Employment Regressions for Hispanic Men, Alternative Aggregate Density Measures, With and Without English Proficiency Interactions

\begin{tabular}{|c|c|c|c|c|c|c|}
\hline & $(1)$ & $(2)$ & (3) & (4) & $(5)$ & $(6)$ \\
\hline Job density measure: & \multicolumn{2}{|c|}{ Jobs/resident } & \multicolumn{2}{|c|}{ Male jobs/male resident } & \multicolumn{2}{|c|}{$\begin{array}{l}\text { Hispanic or white male } \\
\text { jobs/Hispanic or white } \\
\text { male resident }\end{array}$} \\
\hline $\begin{array}{l}\text { doD density } \\
\text { defined for: }\end{array}$ & All & Poor English & All & Poor English & All & Poor English \\
\hline Job density & $\begin{array}{l}.002 \\
(.004)\end{array}$ & $\begin{array}{l}.036 * * \\
(.008)\end{array}$ & $\begin{array}{l}-.002 \\
(.004)\end{array}$ & $\begin{array}{l}.024 * * \\
(.005)\end{array}$ & $\begin{array}{c}-.007^{* *} \\
(.003)\end{array}$ & $\begin{array}{l}.018 * * \\
(.004)\end{array}$ \\
\hline $\mathrm{R}^{2}$ & .057 & .058 & .057 & .058 & .057 & .058 \\
\hline $\begin{array}{l}\text { Jobs/resident } \\
\times \text { poor English }\end{array}$ & $\begin{array}{l}.010^{*} \\
(.005)\end{array}$ & $\begin{array}{l}.061 * * \\
(.011)\end{array}$ & $\begin{array}{l}.007 \\
(.005)\end{array}$ & $\begin{array}{l}.038 * * \\
(.007)\end{array}$ & $\begin{array}{r}-.0002 \\
(.004)\end{array}$ & $\begin{array}{l}.030 * * \\
(.006)\end{array}$ \\
\hline $\begin{array}{l}\text { Jobs/resident } \\
\times \text { good English }\end{array}$ & $\begin{array}{l}-.002 \\
(.004)\end{array}$ & $\begin{array}{l}.031 * * \\
(.007)\end{array}$ & $\begin{array}{l}-.006 \\
(.004)\end{array}$ & $\begin{array}{l}.021 * * \\
(.004)\end{array}$ & $\begin{array}{c}-.010^{* *} \\
(.004)\end{array}$ & $\begin{array}{l}.017 * * \\
(.004)\end{array}$ \\
\hline $\mathrm{R}^{2}$ & .057 & .058 & .057 & .058 & .057 & .058 \\
\hline
\end{tabular}

There are 625,523 observations on Hispanics. Regression estimates are from linear probability models, with standard errors in parentheses. All specifications include controls for age (linear and quadratic terms), marital status (a dummy variable for currently married), highest education (six categories including less than high school, high school degree, some college, Associate's degree, Bachelor's degree, and advanced degree), four controls for English proficiency, residence in the central city, non-central city, and suburban residence, a dummy variable for immigrant status, and MSA fixed effects. All estimates are weighted to account for differences in the probability of having valid place of work data. All standard errors are robust to non-independence of observations within zip code areas heteroscedasticity. ${ }^{* *}$ indicates statistical significance at the 5-percent level, and * at the 10-percent level. See also notes to Table 2. 
Table 5: Employment Regressions for Hispanic Men, Alternative Ethnicity-Specific Density Measures, With and Without English Proficiency Interactions

\begin{tabular}{|c|c|c|c|c|c|c|}
\hline \multirow{3}{*}{$\begin{array}{l}\text { Job density measure: } \\
\text { Job density } \\
\text { defined for: }\end{array}$} & $(1)$ & (2) & (3) & (4) & $(5)$ & $(6)$ \\
\hline & \multicolumn{2}{|c|}{$\begin{array}{c}\text { Non-Hispanic jobs or } \\
\text { Hispanic jobs/Hispanic } \\
\text { resident } \\
\end{array}$} & \multicolumn{2}{|c|}{$\begin{array}{l}\text { Male non-Hispanic jobs or } \\
\text { Hispanic jobs/Hispanic male } \\
\text { resident }\end{array}$} & \multicolumn{2}{|c|}{$\begin{array}{c}\text { Male white jobs or male } \\
\text { Hispanic jobs/Hispanic } \\
\text { male resident }\end{array}$} \\
\hline & All & Poor English & All & Poor English & All & Poor English \\
\hline $\begin{array}{l}\text { Non-Hispanic or white } \\
\text { job density }\end{array}$ & $\begin{array}{l}.001^{* *} \\
(.0003)\end{array}$ & $\begin{array}{l}.0003 \\
(.0007)\end{array}$ & $\begin{array}{l}.001^{* *} \\
(.0002)\end{array}$ & $\begin{array}{l}.001^{* *} \\
(.0004)\end{array}$ & $\begin{array}{l}.001^{* *} \\
(.0003)\end{array}$ & $\begin{array}{l}.003 * * \\
(.002)\end{array}$ \\
\hline Hispanic job density & $\begin{array}{l}.022^{* *} \\
(.006)\end{array}$ & $\begin{array}{l}.016^{* *} \\
(.003)\end{array}$ & $\begin{array}{l}.020 * * \\
(.005)\end{array}$ & $\begin{array}{l}.007 * * \\
(.001)\end{array}$ & $\begin{array}{l}.018^{* *} \\
(.005)\end{array}$ & $\begin{array}{l}.007 * * \\
(.001)\end{array}$ \\
\hline $\mathrm{R}^{2}$ & .058 & .058 & .058 & .058 & .058 & .058 \\
\hline $\begin{array}{l}\text { Non-Hispanic jobs/ } \\
\text { Hispanic resident } \\
\times \text { poor English }\end{array}$ & $\begin{array}{l}.001^{* *} \\
(.0003)\end{array}$ & $\begin{array}{l}-.004 \\
(.004)\end{array}$ & $\begin{array}{l}.0008^{* *} \\
(.0003)\end{array}$ & $\begin{array}{l}-.001 \\
(.002)\end{array}$ & $\begin{array}{l}.001^{* *} \\
(.0004)\end{array}$ & $\begin{array}{l}-.006 \\
(.005)\end{array}$ \\
\hline $\begin{array}{l}\text { Hispanic jobs/ } \\
\text { Hispanic resident } \\
\times \text { poor English }\end{array}$ & $\begin{array}{l}.028^{* *} \\
(.008)\end{array}$ & $\begin{array}{l}.040 * * \\
(.006)\end{array}$ & $\begin{array}{l}.026^{* *} \\
(.007)\end{array}$ & $\begin{array}{l}.016^{* *} \\
(.004)\end{array}$ & $\begin{array}{l}.024^{* *} \\
(.007)\end{array}$ & $\begin{array}{l}.016^{* *} \\
(.004)\end{array}$ \\
\hline $\begin{array}{l}\text { Non-Hispanic jobs/ } \\
\text { Hispanic resident } \\
\times \text { good English }\end{array}$ & $\begin{array}{l}.001^{* *} \\
(.0003)\end{array}$ & $\begin{array}{c}.001 \\
(.001)\end{array}$ & $\begin{array}{l}.0005^{* *} \\
(.0002)\end{array}$ & $\begin{array}{l}.001^{* *} \\
(.0005)\end{array}$ & $\begin{array}{l}.001^{* *} \\
(.0003)\end{array}$ & $\begin{array}{l}.004^{* *} \\
(.002)\end{array}$ \\
\hline $\begin{array}{l}\text { Hispanic jobs/ } \\
\text { Hispanic resident } \\
\times \text { good English }\end{array}$ & $\begin{array}{l}.021^{* *} \\
(.006)\end{array}$ & $\begin{array}{l}.013^{* *} \\
(.002)\end{array}$ & $\begin{array}{l}.018^{* *} \\
(.005)\end{array}$ & $\begin{array}{l}.006^{* *} \\
(.001)\end{array}$ & $\begin{array}{l}.017^{* *} \\
(.004)\end{array}$ & $\begin{array}{l}.005^{* *} \\
(.001)\end{array}$ \\
\hline $\mathrm{R}^{2}$ & .058 & .058 & .058 & .058 & .058 & .058 \\
\hline
\end{tabular}

See notes to Tables 2 and 4. 
Table 6: Employment Regressions for Hispanic Men, Alternative Aggregate Density Measures, With and Without Immigrant Status Interactions

$(2)$

(3)

(4)

(5)

(6)

Hispanic or white male

Job density

measure:

Jobs/resident

Male jobs/male resident jobs/Hispanic or white

Job density male resident

\begin{tabular}{lcccccc} 
defined for: & All & Immigrant & All & Immigrant & All & Immigrant \\
\hline Job density & .002 & $.020^{* *}$ & -.002 & $.017^{* *}$ & $-.007^{* *}$ & $.020^{* *}$ \\
& $(.004)$ & $(.004)$ & $(.004)$ & $(.004)$ & $(.003)$ & $(.005)$ \\
$\mathrm{R}^{2}$ & .057 & .058 & .057 & .058 & .057 & .058 \\
\hline & & & & & & \\
Jobs/resident & .004 & $.024^{* *}$ & .001 & $.020^{* *}$ & -.003 & $.023^{* *}$ \\
$\times$ immigrant & $(.004)$ & $(.005)$ & $(.004)$ & $(.005)$ & $(.004)$ & $(.006)$ \\
Jobs/resident & -.002 & $.016^{* *}$ & -.006 & $.014^{* *}$ & $-.012^{* *}$ & $.017^{* *}$ \\
$\times$ non-immigrant & $(.005)$ & $(.004)$ & $(.005)$ & $(.004)$ & $(.004)$ & $(.006)$ \\
$\mathrm{R}^{2}$ & .057 & .058 & .057 & .058 & .057 & .058 \\
\hline
\end{tabular}

See notes to Tables 2 and 4 . 
Table 7: Employment Regressions for Hispanic Men, Alternative Ethnicity-Specific Density Measures, With and Without Immigrant Status Interactions

\begin{tabular}{|c|c|c|c|c|c|c|}
\hline \multirow{3}{*}{$\begin{array}{l}\text { Job density measure: } \\
\text { Job density } \\
\text { defined for: }\end{array}$} & $(1)$ & $(2)$ & (3) & $(4)$ & $(5)$ & (6) \\
\hline & \multicolumn{2}{|c|}{$\begin{array}{l}\text { Non-Hispanic jobs or } \\
\text { Hispanic jobs/Hispanic } \\
\text { resident } \\
\end{array}$} & \multicolumn{2}{|c|}{$\begin{array}{c}\text { Male non-Hispanic jobs or } \\
\text { Hispanic jobs/Hispanic } \\
\text { male resident }\end{array}$} & \multicolumn{2}{|c|}{$\begin{array}{c}\text { Male white jobs or male } \\
\text { Hispanic jobs/Hispanic } \\
\text { male resident }\end{array}$} \\
\hline & All & Immigrant & All & Immigrant & All & Immigrant \\
\hline $\begin{array}{l}\text { Non-Hispanic or } \\
\text { white job density }\end{array}$ & $\begin{array}{l}.002 * * \\
(.0003)\end{array}$ & $\begin{array}{l}-.0001 \\
(.0013)\end{array}$ & $\begin{array}{l}.001^{* *} \\
(.0002)\end{array}$ & $\begin{array}{l}-.001 \\
(.001)\end{array}$ & $\begin{array}{l}.001^{* *} \\
(.0003)\end{array}$ & $\begin{array}{l}.001 \\
(.001)\end{array}$ \\
\hline Hispanic job density & $\begin{array}{l}.022 * * \\
(.006)\end{array}$ & $\begin{array}{l}.028 * * \\
(.005)\end{array}$ & $\begin{array}{l}.020 * * \\
(.005)\end{array}$ & $\begin{array}{l}.020 * * \\
(.003)\end{array}$ & $\begin{array}{l}.019 * * \\
(.005)\end{array}$ & $\begin{array}{l}.017 * * \\
(.004)\end{array}$ \\
\hline $\mathrm{R}^{2}$ & .058 & .058 & .058 & .058 & .058 & .058 \\
\hline $\begin{array}{l}\text { Non-Hispanic jobs/ } \\
\text { Hispanic resident } \\
\times \text { immigrant }\end{array}$ & $\begin{array}{l}.001^{* *} \\
(.0003)\end{array}$ & $\begin{array}{l}.001 \\
(.001)\end{array}$ & $\begin{array}{l}.001^{* *} \\
(.0003)\end{array}$ & $\begin{array}{l}.0004 \\
(.0010)\end{array}$ & $\begin{array}{l}.001^{* *} \\
(.0003)\end{array}$ & $\begin{array}{l}.002 \\
(.002)\end{array}$ \\
\hline $\begin{array}{l}\text { Hispanic jobs/ } \\
\text { Hispanic resident } \\
\text { × immigrant }\end{array}$ & $\begin{array}{l}.018^{* *} \\
(.006)\end{array}$ & $\begin{array}{l}.024^{* *} \\
(.008)\end{array}$ & $\begin{array}{l}.016^{* *} \\
(.005)\end{array}$ & $\begin{array}{l}.017^{* *} \\
(.005)\end{array}$ & $\begin{array}{l}.015^{* *} \\
(.005)\end{array}$ & $\begin{array}{l}.016^{* *} \\
(.005)\end{array}$ \\
\hline $\begin{array}{l}\text { Non-Hispanic jobs/ } \\
\text { Hispanic resident } \\
\times \text { non-immigrant }\end{array}$ & $\begin{array}{l}.001^{* *} \\
(.000)\end{array}$ & $\begin{array}{l}-.001 \\
(.002)\end{array}$ & $\begin{array}{l}.001^{* *} \\
(.0002)\end{array}$ & $\begin{array}{l}-.001 \\
(.001)\end{array}$ & $\begin{array}{l}.001^{* *} \\
(.0003)\end{array}$ & $\begin{array}{c}.0001 \\
(.0013)\end{array}$ \\
\hline $\begin{array}{l}\text { Hispanic jobs/ } \\
\text { Hispanic resident } \\
\times \text { non-immigrant }\end{array}$ & $\begin{array}{l}.028 * * \\
(.007)\end{array}$ & $\begin{array}{l}.030 * * \\
(.005)\end{array}$ & $\begin{array}{l}.024^{* *} \\
(.006)\end{array}$ & $\begin{array}{l}.021^{* *} \\
(.003)\end{array}$ & $\begin{array}{l}.023^{* *} \\
(.006)\end{array}$ & $\begin{array}{l}.018^{* *} \\
(.004)\end{array}$ \\
\hline $\mathrm{R}^{2}$ & .058 & .058 & .058 & .058 & .058 & .058 \\
\hline
\end{tabular}

See notes to Tables 2 and 4. 
Table 8: Employment Regressions for White Men, Alternative Race/EthnicitySpecific Density Measures, With and Without Own Education Interactions

\begin{tabular}{|c|c|c|c|}
\hline & (1) & (2) & (3) \\
\hline $\begin{array}{l}\text { Job density } \\
\text { measure: }\end{array}$ & \multicolumn{3}{|c|}{$\begin{array}{l}\text { Male non-white jobs or male white jobs/ } \\
\text { white male resident }\end{array}$} \\
\hline $\begin{array}{l}\text { Job density } \\
\text { defined for: }\end{array}$ & All & LTHS+HSD & LTHS \\
\hline $\begin{array}{l}\text { Non-white male } \\
\text { job density } \\
\text { White male job } \\
\text { density } \\
\mathrm{R}^{2} \\
\end{array}$ & $\begin{array}{c}-.011 \\
(.002) \\
.005 \\
(.001) \\
.110 \\
\end{array}$ & $\begin{array}{c}-.004 \\
(.001) \\
.010 \\
(.001) \\
.110 \\
\end{array}$ & $\begin{array}{c}-.002 \\
(.0003) \\
.016 \\
(.001) \\
.110 \\
\end{array}$ \\
\hline $\begin{array}{l}\text { Non-white male jobs/ } \\
\text { white male resident } \\
\times \text { own educ. LTHS }\end{array}$ & $\begin{array}{l}-.014 \\
(.003)\end{array}$ & $\begin{array}{l}-.012 \\
(.001)\end{array}$ & $\begin{array}{l}-.007 \\
(.001)\end{array}$ \\
\hline $\begin{array}{l}\text { White male jobs/ } \\
\text { white male resident } \\
\times \text { own educ. LTHS }\end{array}$ & $\begin{array}{l}-.010 \\
(.002)\end{array}$ & $\begin{array}{l}.009 \\
(.002)\end{array}$ & $\begin{array}{c}.036 \\
(.003)\end{array}$ \\
\hline $\begin{array}{l}\text { Non-white male jobs/ } \\
\text { white male resident } \times \\
\text { own educ. HSD }\end{array}$ & $\begin{array}{l}-.022 \\
(.003)\end{array}$ & $\begin{array}{l}-.012 \\
(.002)\end{array}$ & $\begin{array}{l}-.006 \\
(.001)\end{array}$ \\
\hline $\begin{array}{l}\text { White male jobs/ } \\
\text { white male resident } \\
\times \text { own educ. HSD }\end{array}$ & $\begin{array}{l}.003 \\
(.002)\end{array}$ & $\begin{array}{l}.015 \\
(.002)\end{array}$ & $\begin{array}{l}.029 \\
(.002)\end{array}$ \\
\hline $\begin{array}{l}\text { Non-white male jobs/ } \\
\text { white male resident } \\
\times \text { own educ. SCOL }\end{array}$ & $\begin{array}{l}-.005 \\
(.001)\end{array}$ & $\begin{array}{c}-.001 \\
(.0004)\end{array}$ & $\begin{array}{l}-.0003 \\
(.0002)\end{array}$ \\
\hline $\begin{array}{l}\text { White male jobs/ } \\
\text { white male resident } \\
\times \text { own educ. SCOL }\end{array}$ & $\begin{array}{l}.007 \\
(.001)\end{array}$ & $\begin{array}{l}.008 \\
(.001)\end{array}$ & $\begin{array}{l}.010 \\
(.001)\end{array}$ \\
\hline $\mathrm{R}^{2}$ & .110 & .110 & .110 \\
\hline
\end{tabular}

There are 4,030,425 observations. See note to Tables 2 and 4. Note that "non-white" includes Hispanics, blacks, and others. 
Table 9: Employment Regressions for Hispanic Men, Ethnicity-Specific Job Density Measures, With and Without English Proficiency Interactions, Cities with High Growth Rates of Non-U.S. Born Hispanics (1990-2000)

\begin{tabular}{|c|c|c|c|c|}
\hline & (1) & (2) & (3) & (4) \\
\hline $\begin{array}{l}\text { Growth rate of non-U.S. born } \\
\text { Hispanics in MSA/PMSA: }\end{array}$ & All & Top 50 & Top 30 & Top 10 \\
\hline $\begin{array}{l}\text { Non-Hispanic } \\
\text { job density }\end{array}$ & $\begin{array}{l}.001^{* *} \\
(.0003)\end{array}$ & $\begin{array}{l}-.0001 \\
(.0003)\end{array}$ & $\begin{array}{l}-.0002 \\
(.0002)\end{array}$ & $\begin{array}{c}-.001 \\
(.0008)\end{array}$ \\
\hline Hispanic job density & $\begin{array}{l}.022 * * \\
(.006)\end{array}$ & $\begin{array}{l}.040 * * \\
(.009)\end{array}$ & $\begin{array}{l}.037 * * \\
(.012)\end{array}$ & $\begin{array}{l}.088^{* *} \\
(.028)\end{array}$ \\
\hline $\mathrm{R}^{2}$ & .058 & .045 & .044 & .033 \\
\hline $\begin{array}{l}\text { Non-Hispanic jobs/ } \\
\text { Hispanic resident } \\
\times \text { poor English }\end{array}$ & $\begin{array}{l}.001 * * \\
(.0003)\end{array}$ & $\begin{array}{c}.0003 \\
(.0003)\end{array}$ & $\begin{array}{l}-.00003 \\
(.0004)\end{array}$ & $\begin{array}{l}-.001 \\
(.001)\end{array}$ \\
\hline $\begin{array}{l}\text { Hispanic jobs/ } \\
\text { Hispanic resident } \\
\times \text { poor English }\end{array}$ & $\begin{array}{l}.028^{* *} \\
(.008)\end{array}$ & $\begin{array}{l}.043^{* *} \\
(.011)\end{array}$ & $\begin{array}{l}.049 * * \\
(.024)\end{array}$ & $\begin{array}{l}.131^{* *} \\
(.032)\end{array}$ \\
\hline $\begin{array}{l}\text { Non-Hispanic jobs/ } \\
\text { Hispanic resident } \\
\times \text { good English }\end{array}$ & $\begin{array}{l}.001 * * \\
(.0003)\end{array}$ & $\begin{array}{l}-.0002 \\
(.0003)\end{array}$ & $\begin{array}{l}-.003 \\
(.002)\end{array}$ & $\begin{array}{l}-.001 \\
(.001)\end{array}$ \\
\hline $\begin{array}{l}\text { Hispanic jobs/ } \\
\text { Hispanic resident } \\
\times \text { good English }\end{array}$ & $\begin{array}{l}.021 * * \\
(.006)\end{array}$ & $\begin{array}{l}.040^{* *} \\
(.009)\end{array}$ & $\begin{array}{l}.034 * * \\
(.010)\end{array}$ & $\begin{array}{l}.076^{* *} \\
(.029)\end{array}$ \\
\hline $\mathrm{R}^{2}$ & .058 & .045 & .044 & .033 \\
\hline $\mathrm{N}$ & 625,523 & 179,880 & 71,228 & 15,794 \\
\hline
\end{tabular}

See notes to Tables 2 and 4. The specification corresponds to column (1), Table 5. 
Appendix Table A1: Top 50 Metropolitan Areas by Percentage Growth in Non-U.S. Born Hispanic Males, 1990 to 2000

\begin{tabular}{|c|c|c|c|c|c|c|c|c|c|}
\hline & Metropolitan area & 1990 & 2000 & \% Change & & Metropolitan area & 1990 & 2000 & \% Change \\
\hline 1 & Boise City, ID & 80 & 6,404 & $7905.0 \%$ & 26 & $\begin{array}{l}\text { Providence-Fall River- } \\
\text { Pawtucket, MA/RI }\end{array}$ & 5,772 & 21,014 & $264.1 \%$ \\
\hline 2 & Nashville, TN & 480 & 15,292 & $3085.8 \%$ & 27 & Milwaukee-Waukesha, WI & 6,120 & 22,065 & $260.5 \%$ \\
\hline 3 & $\begin{array}{l}\text { Greensboro-Winston Salem-High Point, } \\
\text { NC }\end{array}$ & 795 & 21,347 & $2585.2 \%$ & 28 & Louisville, KY/IN & 996 & 3,539 & $255.3 \%$ \\
\hline 4 & Omaha, NE/IA & 588 & 11,073 & $1783.2 \%$ & 29 & Baton Rouge, LA & 660 & 2,166 & $228.2 \%$ \\
\hline 5 & Indianapolis, IN & 832 & 13,049 & $1468.4 \%$ & 30 & Cincinnati OH/KY/IN & 852 & 2,611 & $206.5 \%$ \\
\hline 6 & Spokane, WA & 75 & 651 & $768.0 \%$ & 31 & Fort Worth-Arlington, TX & 21,420 & 61,753 & $188.3 \%$ \\
\hline 7 & Atlanta, GA & 12,460 & 101,271 & $712.8 \%$ & 32 & Dallas, TX & 73,290 & 209,709 & $186.1 \%$ \\
\hline 8 & Grand Rapids, MI & 1,748 & 13,473 & $670.8 \%$ & 33 & Orlando, FL & 24,840 & 71,050 & $186.0 \%$ \\
\hline 9 & Tacoma, WA & 930 & 5,865 & $530.6 \%$ & 34 & Austin, TX & 15,190 & 43,276 & $184.9 \%$ \\
\hline 10 & Salt Lake City-Ogden, UT & 4,896 & 30,537 & $523.7 \%$ & 35 & Fort Lauderdale, FL & 27,948 & 79,555 & $184.7 \%$ \\
\hline 11 & Raleigh-Durham-Chapel Hill, NC & 2,220 & 13,829 & $523.0 \%$ & 36 & $\begin{array}{l}\text { West Palm Beach-Boca } \\
\text { Raton-Delray Beach, FL }\end{array}$ & 17,736 & 48,286 & $172.2 \%$ \\
\hline 12 & Columbus, $\mathrm{OH}$ & 1,104 & 6,141 & $456.3 \%$ & 37 & Pensacola, FL & 696 & 1,832 & $163.2 \%$ \\
\hline 13 & Charlotte-Gastonia-Rock Hill, SC & 2,955 & 16,291 & $451.3 \%$ & 38 & Vallejo-Fairfield-Napa, CA & 8,125 & 21,112 & $159.8 \%$ \\
\hline 14 & Colorado Springs, CO & 990 & 5,119 & $417.1 \%$ & 39 & Wichita, KS & 2,358 & 6,051 & $156.6 \%$ \\
\hline 15 & Denver-Boulder-Longmont, CO & 15,000 & 74,387 & $395.9 \%$ & 40 & Detroit, MI & 8,607 & 19,968 & $132.0 \%$ \\
\hline 16 & Minneapolis-St. Paul, MN & 4,784 & 23,687 & $395.1 \%$ & 41 & Monmouth-Ocean, NJ & 6,825 & 15,678 & $129.7 \%$ \\
\hline 17 & Lakeland-Winterhaven, FL & 2,856 & 13,774 & $382.3 \%$ & 42 & Washington, DC/MD/VA & 61,866 & 141,329 & $128.4 \%$ \\
\hline 18 & Portland-Vancouver, OR & 6,832 & 32,240 & $371.9 \%$ & 43 & Stockton, CA & 13,975 & 30,748 & $120.0 \%$ \\
\hline 19 & Fort Wayne, IN & 704 & 3,089 & $338.8 \%$ & 44 & St. Louis, MO-IL & 2,515 & 5,520 & $119.5 \%$ \\
\hline 20 & Las Vegas, NV & 17,186 & 71,557 & $316.4 \%$ & 45 & Oklahoma City, OK & 6,137 & 13,339 & $117.4 \%$ \\
\hline 21 & Jacksonville, FL & 1,968 & 8,169 & $315.1 \%$ & 46 & Boston, MA & 30,290 & 65,430 & $116.0 \%$ \\
\hline 22 & Kansas City, MO-KS & 3,180 & 12,900 & $305.7 \%$ & 47 & Houston-Brazoria, TX & 131,642 & 282,265 & $114.4 \%$ \\
\hline 23 & Phoenix, AZ & 38,025 & 149,672 & $293.6 \%$ & 48 & $\begin{array}{l}\text { Tampa-St. Petersburg- } \\
\text { Clearwater, FL }\end{array}$ & 25,644 & 54,748 & $113.5 \%$ \\
\hline 24 & Seattle-Bellevue-Everett, WA & 7,230 & 28,228 & $290.4 \%$ & 49 & Oakland, CA & 46,163 & 98,211 & $112.7 \%$ \\
\hline 25 & Tulsa, OK & 2,125 & 7,879 & $270.8 \%$ & 50 & Columbia, SC & 1,095 & 2,328 & $112.6 \%$ \\
\hline
\end{tabular}

The numbers in this table are calculations from IPUMS. The variable "METAREA-detailed” was used to identify metropolitan areas. The total numbers of immigrant Hispanic males are weighted. 
Appendix Table A2: Employment Regressions for Hispanic Men, Ethnicity-Specific Job Density Measures Defined for Poor English Speakers, With and Without English Proficiency Interactions, Cities with High Growth Rates of Non-U.S. Born Hispanics (1990-2000)

\begin{tabular}{lcccc}
\hline & $(1)$ & $(2)$ & $(3)$ & $(4)$ \\
\hline $\begin{array}{l}\text { Growth rate of non-U.S. born } \\
\text { Hispanics in MSA/PMSA: }\end{array}$ & All & Top 50 & Top 30 & Top 10 \\
\hline $\begin{array}{l}\text { Density defined for poor English } \\
\text { speakers }\end{array}$ & & & & \\
\hline $\begin{array}{l}\text { Non-Hispanic } \\
\text { job density }\end{array}$ & .0003 & -.002 & $-.004^{* *}$ & .016 \\
Hispanic job density & $(.0007)$ & $(.003)$ & $(.002)$ & $(.011)$ \\
& $.016^{* *}$ & $.014^{* *}$ & $.011^{* *}$ & $.023^{* *}$ \\
\hline $\begin{array}{l}\text { Non-Hispanic jobs/ } \\
\text { Hispanic resident }\end{array}$ & $(.003)$ & $(.004)$ & $(.003)$ & $(.010)$ \\
$\times$ poor English & -.004 & $-.011^{*}$ & $-.017^{* *}$ & .017 \\
$\begin{array}{l}\text { Hispanic jobs/ } \\
\text { Hispanic resident }\end{array}$ & $(.004)$ & $(.006)$ & $(.005)$ & $(.016)$ \\
$\times$ poor English & & & & $.041^{* *}$ \\
$\begin{array}{l}\text { Non-Hispanic jobs/ } \\
\text { Hispanic resident }\end{array}$ & $.040^{* *}$ & $.041^{* *}$ & $.029^{* *}$ & $(.019)$ \\
$\times$ good English & $(.006)$ & $(.012)$ & $(.009)$ & .014 \\
$\begin{array}{l}\text { Hispanic jobs/ } \\
\text { Hispanic resident }\end{array}$ & & & & $(.012)$ \\
$\times$ good English & .001 & -.001 & -.003 & \\
\hline
\end{tabular}

See notes to Tables 2 and 4 . The specifications in the top two panels correspond to column (2), Table 5. 